\author{
D.G. Mamrayeva ${ }^{1}$, A.B. Toxambayeva ${ }^{2,}$, , G.B. Mamrayeva ${ }^{3}$, L.A. Rodina ${ }^{4}$ \\ ${ }^{1,2}$ Karaganda University named after academician Ye.A. Buketov, Kazakhstan \\ ${ }^{3}$ Karaganda College of Actual Education «Bolashaq», Kazakhstan \\ ${ }^{4}$ Omsk State University named after F.M. Dostoevsky \\ 1dina2307@mail.ru, 2aluatoxambayeva@gmail.com, ${ }^{3} m a m r a e v a g @ m a i l . r u,{ }^{4}$ rodinala@omsu.ru \\ ${ }^{1}$ https://orcid.org/0000-0001-8508-7317, ${ }^{2}$ https://orcid.org/0000-0002-6274-0878, \\ ${ }^{4}$ https://orcid.org/0000-0003-3451-3771 \\ ${ }^{1}$ Scopus Author ID: 55357690300, ${ }^{1}$ Researcher ID:N-6945-2015 \\ ${ }^{4}$ Scopus Author ID:57211793604, ${ }^{4}$ Reseacher ID: A-7566-2017
}

\title{
Theoretical aspects of studying of the innovations commercialization process
}

\begin{abstract}
Object: to consider theoretically-methodological aspects, also management mechanisms by the process of innovations commercialization.

Methods: methods of system and structural analysis are used in the article, allowing to consider the scientific problems investigated in the article in a comprehensive manner, also draw conclusions that fully reveal the essence and specifics of the studied research object.

Findings: modern trends in the theory of innovations commercialization considered in the article, studied the conceptual apparatus in the field of innovations commercialization; the process of innovations commercialization is investigated, the relationship of its participants is established, the ways of its implementation are determined; the stages and phases of the innovation process are concretized.

Conclusions: the concept of innovations commercialization, the innovation process, the stages of its implementation is investigated in presented scientific article. The article describes the main phases and stages of the innovation process, analyzes the model of commercialization of innovations, also the criteria of the degree of its successful implementation. The ways of innovations commercialization, which are the most relevant today are characterized, the potential profit for a certain period, the main items of the enterprise income and expenses with successful implementation of the process of innovations commercialization are presented. The formulas of the potential profit calculating for a certain period of innovative product commercialization are reflected. In the analyzed scientific studies of foreign and domestic researchers, by the authors concluded that in the conditions of modern economic development, the restructuring of a number of the world countries economies the into digital and innovative components, commercialization is one of the most important components of the successful implementation of the innovation results, therefore, it is advisable to carry out this process at an earlier stage, starting from the moment of fundamental research by companies in the structure of their activities in the field of R\&D.
\end{abstract}

Keywords: innovations, innovations commercialization process, innovation stages, innovative project, commercialization of results, R\&D, innovations commercialization mechanism, innovations commercialization scheme.

\section{Introduction}

The current global economic transformations require rapid and dynamic development of innovations in many countries. Noncompliance of the innovation cycle principles and investment in problem areas of the economy may result in decrease of the country's competitiveness in the world market. Therefore, a country's level of innovation activity is rightly considered a key factor in its success in the international arena. And, as a consequence, the solution of the enterprises social and economic problems in developed countries is innovation and the level of technological development.

The processes of technological development in the post-industrial economy help to transform one type of resource into another, stimulating the process of forming new wealth. Actions aimed to preventing (reduction) of the economic gap between developed and developing countries highlighted the relevance of creating a favorable environment for innovation in developing countries, contributing to the development of innovation and supporting of the business entities activities. Achieving of this goal is possible thanks to the development and implementation of an innovation management system in the company. The system should take into account the special conditions of economic activity in developing countries, using in full

\footnotetext{
*Corresponding author.

E-mail address: aluatoxambayeva@gmail.com
} 
volume the positive dynamics of developed countries. Considering of the current market instability, investment return in new products or technologies cannot be guaranteed. However, there are ways to reduce risks and increase probability of successful achieving implementation of innovative projects. One of these methods is the innovations commercialization as an element of a separate business process.

The process of commercialization, extended to the entire life cycle of innovative products, contributes to an increase of the product using efficiency, to discovery of a new practically useful characteristics, expansion of consumers and sales markets (Olefirenko O., Shevliuga O., 2017).

\section{Literature Review}

Research of the innovative development processes of the country as a whole and the behavior of business entities, in particular, are widely reflected in the scientific literature. At the same time, fragmentary attention is paid to the problems of the innovations commercialization process. Many scientists have considered questions related with the innovation commercialization in their writings. According to the author Bozeman B. (1997), commercialization is successful when projects are more likely to lead to the commercialization of a product if they are initiated either by the company's research and development managers or by top managers of the company. Commercialization of high-tech products it is a process of establishing, selling and promoting of high-tech products in the market, which provides the expected economic benefits for the industry. An analysis of statistical, expert and empirical data shows that the problem for the domestic industry is a commercialization of high-tech products, and not its creation (Shpak et al., 2014).

Commercialization is an important issue of improving economic efficiency. Kalynychenko (2012) proposed a marketing approach for the commercialization of the innovative activity results in the industry, which consists of the stages of commercialization, marketing, compliance of the project management processes and design application, scenario and network planning. Innovations commercialization mainly refers to the prosess of the scientific discoveries transformation and inventions into market products and services, mainly by licensing of patents for companies or creating "start-up» companies, that depend on the transfer of university intellectual property to them (Mohannak K., Samtani L., 2014).

The interpretation of the concept of "commercialization", proposed by different authors, is characterized by diversity. In particular, the Law of the Republic of Kazakhstan dated October 31, 2015 № 381-V "About commercialization of the results of scientific and (or) scientific-technical activities" (as amended on June 25,2020) interprets the commercialization of the results of scientific and (or) scientific and technical activities in the following way - it is "activity, related with the practical application of the results of scientific and (or) scientific-technical activities, including the results of intellectual activity, with the aim of bringing new or improved goods, processes and services to the market, directed to the income generating (art. 1, p.3)" [Law of the Republic of Kazakhstan].

According to the scientist J. Kozmetsky, commercialization is "a process with the help of the results of R\&D are timely transformed into products and services on the market" (Kozmetsky J., 1999). Authors Ya.N. Grik and E.N. Monastyrny, are considering the commercialization of an innovative idea in the form of income receiving from its sale, or using in their own production (Grik Y.N., Monastyrny E.N., 2004). The commercialization process, according to V.V. Glukhov, S.B. Korobko, T.V. Marinina is divided into two directions:

1. "using of intellectual property in the business activity of an enterprise";

2. "commercialization of an innovative object by introducing it into economic circulation, as a result of which a profit will be obtained that reimburses the costs of scientific research, the result of which is an innovative object" (Glukhov V.V. et al., 2003) (Table 1).

Table 1. Approaches to the definition of the "innovation commercialization process" essence

\begin{tabular}{|l|l|}
\hline \multicolumn{1}{|c|}{ Author } & \multicolumn{1}{c|}{ Definition } \\
\hline \hline \multicolumn{1}{|c|}{ J. Kozmetsky (1999) } & \multicolumn{1}{c|}{2} \\
\hline Y.N. Grik, E.N. Monastyrny (2004) & $\begin{array}{l}\text { "Commercialization is a process as a result of which R\&D results trans- } \\
\text { forms into products and services on the market in due time". }\end{array}$ \\
& $\begin{array}{l}\text { "Innovative idea commercialization represents the receipt of income } \\
\text { " Innovative ideas commercialization means receiving a profit from the } \\
\text { sale or using it in the production process." }\end{array}$ \\
\hline
\end{tabular}




\begin{tabular}{|c|c|}
\hline $\begin{array}{l}\text { V.V. Glukhov, S.B. Korobko, } \\
\text { T.V. Marinina (2003) }\end{array}$ & $\begin{array}{l}\text { "The commercialization process is divided into two directions. The first } \\
\text { is associated with the using of intellectual property in the enterprise eco- } \\
\text { nomic activities, and the second - with the innovative product commer- } \\
\text { cialization through its introduction into the economic process". }\end{array}$ \\
\hline K.V. Orlova (2017) & $\begin{array}{l}\text { "From a finance, the innovation commercialization is an investment pro- } \\
\text { ject". }\end{array}$ \\
\hline $\begin{array}{l}\text { M. Belitski, A. Aginskaja, R. Marozau } \\
\text { (2018) }\end{array}$ & $\begin{array}{l}\text { "The process of research commercialization is a multi-level and involves } \\
\text { interactions between an individual researcher, a university and the exter- } \\
\text { nal environment». }\end{array}$ \\
\hline P.C. Lai (2018) & $\begin{array}{l}\text { «Commercialization is the point where innovation products or services } \\
\text { are accepted by the marketplace». }\end{array}$ \\
\hline M.O. Iskoskov, V.Ch. Dana (2013) & $\begin{array}{l}\text { «At implementation of innovation, the promotion of innovative products } \\
\text { is traditionally defined as commercialization». }\end{array}$ \\
\hline T. Dehghani (2015). & $\begin{array}{l}\text { «Generally, commercialization can be categorized into three different } \\
\text { layers of infrastructure, namely technical and market issues, attitudes } \\
\text { and policies, and services. There appears to be a widely expressed belief } \\
\text { that people's negative attitudes may impede the commercialization cycle. } \\
\text { Experience shows that changes in scientific and technological policies of } \\
\text { different countries have helped them make a giant leap in technology } \\
\text { development». }\end{array}$ \\
\hline S.K. Slak-Madsen et al. (2017) & $\begin{array}{l}\text { "Commercialization is seen as an ability of market participants to } \\
\text { achieve acceptance by other market participants of its advantageous of- } \\
\text { fers". }\end{array}$ \\
\hline D.S. Rogers et al. (2004) & $\begin{array}{l}\text { "Commercialization is a delivery chain management process that pro- } \\
\text { vides a framework for developing and bringing new products to market } \\
\text { in collaboration with customers and suppliers". }\end{array}$ \\
\hline V. Dewangan, M. Godse (2014) & $\begin{array}{l}\text { «Commercialization of ideas, which involves scaling up the innovation } \\
\text { and formally introducing it to the market and also includes brand build- } \\
\text { ing, market promotion and distribution activities». }\end{array}$ \\
\hline $\begin{array}{l}\text { L. Aarikka-Stenroos, B. Sandberg, T. } \\
\text { Lehtimäki (2014) }\end{array}$ & $\begin{array}{l}\text { «Commercialization tends to refer to how an innovator firmcan accrue } \\
\text { income from its new product, service, concept, or technology; it includes } \\
\text { divergent, strategic and tactical planning, and marketing activities con- } \\
\text { cerning the product/concept, launch, and interactive activities with po- } \\
\text { tential buyers and other relevant players». }\end{array}$ \\
\hline B. El-Haj-Hassan (2012) & $\begin{array}{l}\text { «The commercialization of an innovation can be defined as the process } \\
\text { by which firms transform knowledge, discoveries, and inventions into } \\
\text { new or significantly improved products and services that satisfy custom- } \\
\text { ers' needs». }\end{array}$ \\
\hline $\begin{array}{l}\text { The Heart of Successful Commercializa- } \\
\text { tion report released by Industry Canada } \\
(2006)\end{array}$ & $\begin{array}{l}\text { «Commercialization is defined as being - a complex, integrated system } \\
\text { anchored in the world of business». }\end{array}$ \\
\hline J.-M. Nikkanen (2018) & $\begin{array}{l}\text { "When innovations are commercialized successfully, knowledge achieve } \\
\text { its full benefits and produce returns from investments. Thus, commer- } \\
\text { cialization can be seen as important factor of economic growth. It also } \\
\text { enables the availability of innovation to the end customers». }\end{array}$ \\
\hline J.F. Jordan (2010) & $\begin{array}{l}\text { "Commercialization is a process of different steps and different actions } \\
\text { and the outcome is to bring innovation to the market». }\end{array}$ \\
\hline
\end{tabular}

Most of the analyzed scientific definitions reveal certain aspects of the innovations commercialization, which include the choice of the form and the main participants of the process, the identification of marketing opportunities for innovative products and search of the best source of funding for the innovations commercialization. In other words, commercialization is seen as a stage of the innovation process, from the the beginning of production until the end of the decline of the product's life cycle. Domestic authors consider commercialization as a process of using the results of $R \& D$, through which a new product or service is introduced to the common market, or involves the participation of investors to raise funds for the implementation of this innovation. While foreign scientists consider the process of commercialization as a factor of economic growth, ensuring the availability of innovations for end consumers. Effective process implementation allows management to coordinate the efficient flow of new products through the de- 
livery chain, helping participants ramp up production, logistics, marketing, and other related activities to support product commercialization.

Thus, commercialization is a difficult process, consisting of separate stages, by which enterprises transform knowledge, discoveries and inventions into a new or upgraded products and services, that satisfy the needs of consumers. The result of this process is the introduction of innovations to the market.

Applied to an industrial enterprise, commercialization should be considered as an effective way for this enterprise to use the results of its innovation activities, which bring benefits (advantages) not only in the form of return on investment in $\mathrm{R} \& \mathrm{D}$, but also in the form of an increase in production volumes, an improvement of the produced goods quality and reducing of the cost of production and, as a consequence - price. Commercialization able take on the role of the main driving force aimed for creating and rejuvenation of old industrial sectors and ensure the competitiveness of the industrial enterprise in the market.

\section{Methods}

In presented scientific article are used the following scientific methods: deductive method used to analyze the innovations commercialization, with a view of determination of the evaluating of their application; a method of scientific analysis, directed at studying of the theoretical foundations of innovations commercialization with the definition of phenomena that determine the mechanism of its application.

The synthesis method allows to obtain a broad research results, to form and generalize conclusions about current trends and phenomena in the theories of innovation commercialization. The graphic method and abstract logic method are used.

In addition, scientific provisions on planning innovation activities, analyzing of innovation processes, also general scientific methods of cognition are used in the work: complex and abstract-logical. The search for literature sources was carried out using keywords related to the commercialization process in three main databases: Scopus (sciencedirect.com), Clarivate Analytics (webofknowledge.com) and RSCI (elibrary.ru). As part of this process, more than 100 articles of experts, specializing in the sphere of scientific developments commercialization and the implementation of effective innovation activity in industrial enterprises were analyzed.

\section{Results}

According to the report "Global Innovation Index", presented on September 2, 2020 (GII, Global Innovation Index), in which results of a comparative analysis of the 131 countries innovation systems are reflected, indicating the rating of their innovative development, leading positions were taken by countries such as Switzerland, Sweden and the United States. The Republic of Kazakhstan is in 77th place, having strengthened it by two positions compared to this same time last year (Global Innovation Index, 2020).

Today, in order to get the final positive result with the maximum possible effect as a result of using the created innovation, it is necessary to resolve the issue related to the placement of this innovation on the market, that is, to ensure the process of its commercialization.

Many scientists identify the concept of innovation commercialization with the term "innovation process", during which novelty is transformed into innovation. For this reason, by researchers quite often commercialization is considered as a stage of the innovation process. For example, the innovation process according to Yu.P. Morozov is considered as follows: "The innovation process includes the acquisition and commercialization of inventions, new technologies, types of products and services, organizational, technological, economic, social or other solutions, also the results of intellectual activity, which are carried out in four stages" (Morozov Yu.P., 1997). The first step is conducting of fundamental researches in various higher education institutions, industry professional institutions, research institutes and laboratories. The second stage is associated with the stage of applied research, which allows to abandon from hopeless projects before the implementation stage. The third stage is the stage of implementation of developments, the stage of commercialization is the final fourth stage - from the moment of launching into production, entering to the market till stagnation of the product. In the innovation process, from the point of view of the researcher A.A. Trifilova the following main stages are distinguished (Trifilova A.A., 2005): fundamental researches; scientifically-research works; R\&D; commercialization and production phase; sale of goods, also of licenses and patents; and the final stage is the completion of the innovation. 
Trifilova A.A., in comparison with Morozov Yu.P., associates the commercialization process with the life cycle of a product to the least extent. Thus, considering the process of commercialization according to Yu.P. Morozov and A.A. Trifilova, the following scheme was developed by the authors (Figure 1):

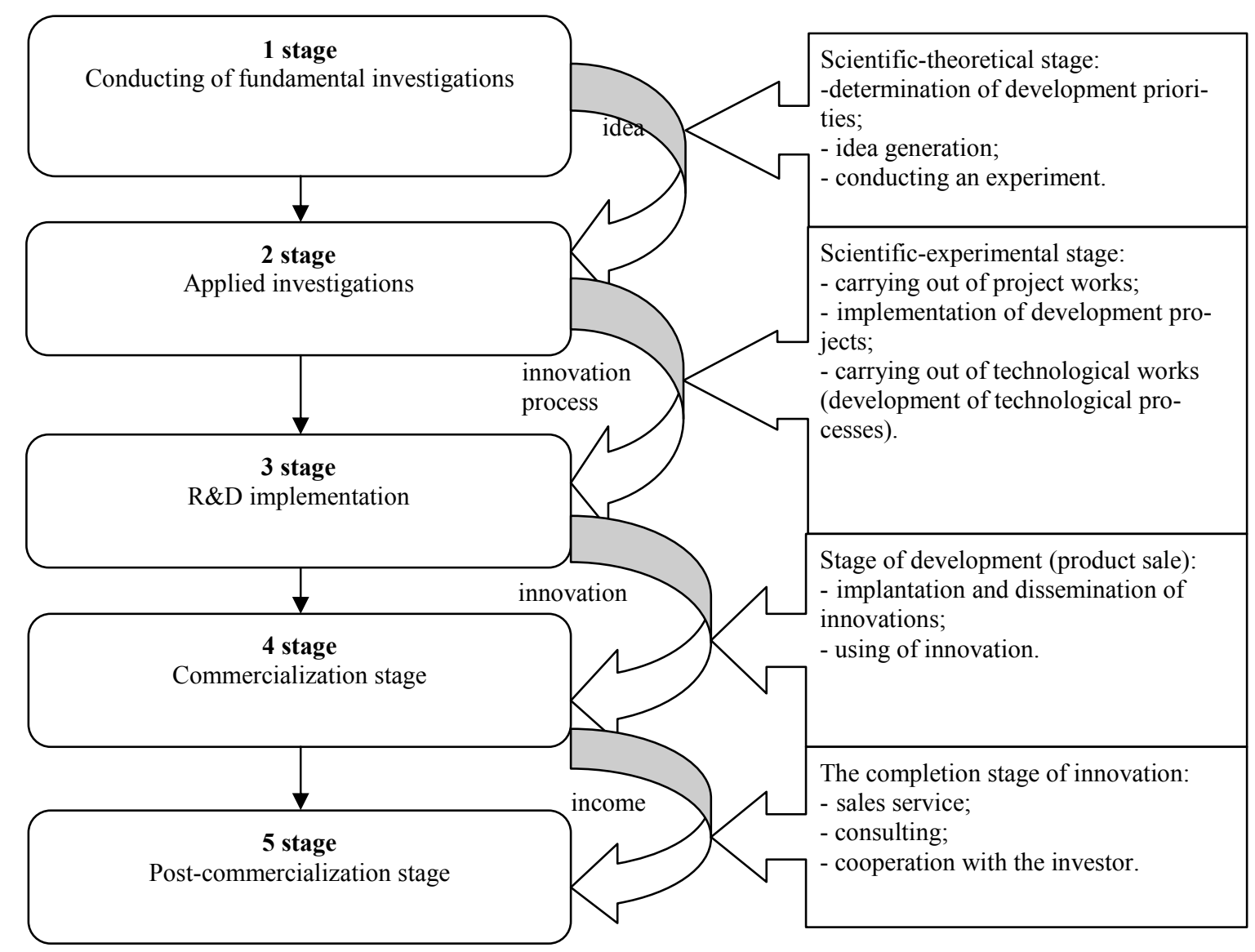

Figure 1. The process of innovation commercialization

Note - compiled by the authors on the basis of source (Trifilova A.A., 2005)

Studying the issues of innovation commercialization, it is important from the beginning of the innovation life cycle to analyze and record data, obtained as a result of fundamental researches. At the same time, the results of the analysis of the innovation commercialization can have an impact on the further process of introducing innovations, which can lead to timely rejection of it.

According to the author Mamrayeva D.G., the innovation commercialization model includes four important blocks: analysis of fundamental researches; analysis of applied researches; analysis of marketing researches; analysis of the results of innovation implementation (Figure 2).

The first stage of the innovations commercialization model has the following characteristics:

- conducting a technological audit of the innovation;

- intermediate conducting of investment risks;

- analysis of profitability and level of commercialization.

The following types of work are typical for the second stage of innovations commercialization:

- carrying out of examination of applied, exploratory researches;

- assessment and monitoring of investment risks;

- carrying out of the analysis effectiveness and commercialization degree.

At the third stage "Analysis of marketing researches", the analysis of information received on the basis of design and project work is being performed in three main areas: 1. monitoring and assessment of investment risks; 2. marketing researches of product sales markets; 3 . analysis of the products competitiveness.

In order to determine the effectiveness of the commercialization model used at the fourth stage, it is necessary to conduct such types of work as: marketing researches of the implemented innovation product; 
evaluating and determining of the effectiveness level of the business plan implementation, written at the stage of development work; monitoring the degree of innovations commercialization.

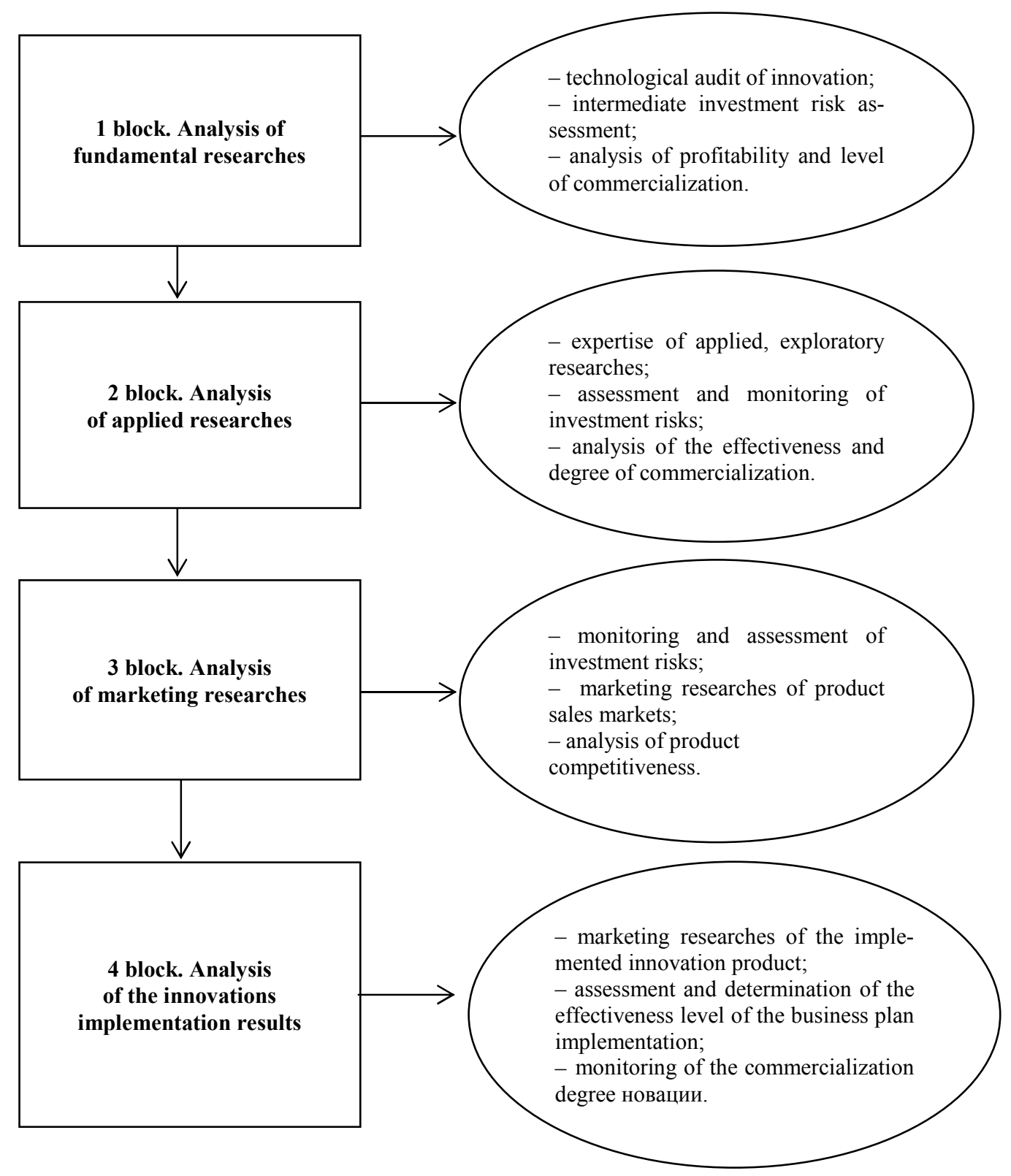

Figure 2. The model of innovations commercialization, proposed by D.G. Mamrayeva

Note-compiled by the authors on the basis of source (Mamrayeva D.G., 2017)

In order to conduct a comprehensive analysis of the degree of product commercialization, it is necessary to take into account the criteria for the degree of innovation commercialization, which are divided into external (market needs and its conjuncture, the presence of competitors, effective demand, consumer needs, competitive products, market capacity, its growth rate, etc.) and internal (values of economic and social efficiency of innovation; innovative potential of the enterprise; the volume of funds directed to R\&D; the level of personnel innovation activity; personnel proportion, the coefficient of property involved in R\&D; necessary companies' resources for implementation of the innovation project, etc.) (Mamrayeva D.G., 2017).

Based on the conducted research, that reveals the essence of the commercialization process, the following scheme for innovations commercialization compiled by the authors (Figure 3). 


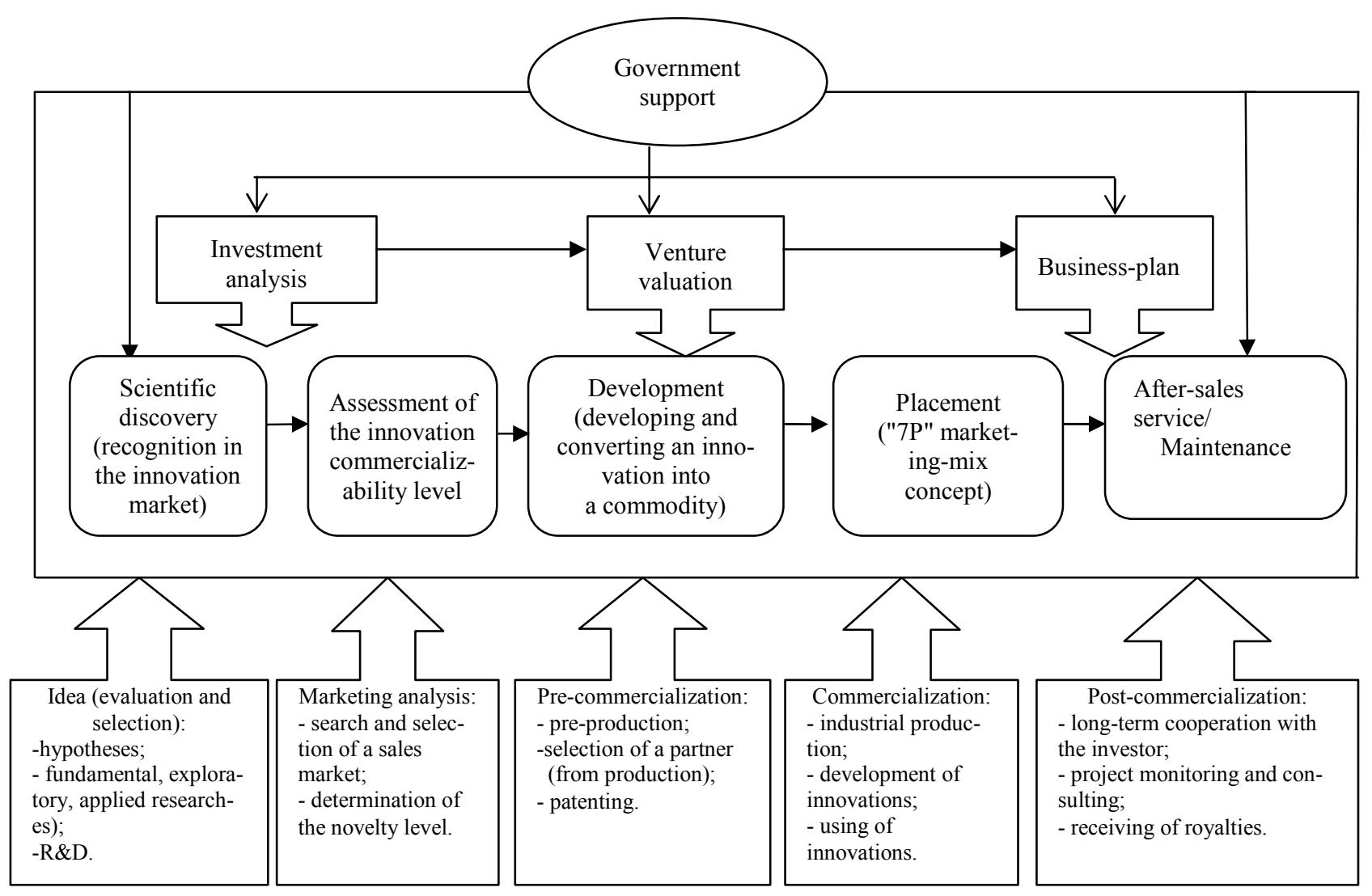

Figure 3. Scheme of innovations commercialization

Note-compiled by the authors on the basis of source (Mamrayeva D.G., 2017)

As shown in Figure 3, the process of innovations commercialization consists of a number of scientific and organizational, financial, technological, commercial activities that contribute to the creation of innovation.

Commercialization is a process that involves the actual useing of research and development results aimed at bringing to market new, better modernized products, services or processes with a commercial effect. Usually this process begins at the stage of scientific discovery, that is, in the process of evaluating and selecting of idea, search for an investor. After that, research and development work (R\&D) is carried out, which have the following characteristics:

1) aimed at obtaining and using of new knowledge, including exploratory, applied scientific researches directed to implementing of new knowledge for achieving of practical goals and solve specific problems. These works have an experimental and theoretical character, because they have the goal to get more new knowledge regarding the trends in the functioning and development of man and society as a whole;

2) directed to the implementation of new knowledge necessary to solve of technological, engineering, socio-economic and other problems, which contributes to the functioning of science, technology and production as a whole;

3) based on knowledge obtained as a result of scientific researches, including experimental developments. The information obtained on the basis of practical experience is aimed at preserving human life and health, creating new materials, products, processes, devices, services, systems or methods and their further improvement (Lukash Yu.A., 2004).

At the next stage - the innovation development and its transformation into a product - an analysis of marketing research, connected with the search and selection of markets for goods is carried out, preparatory works for the production process. At this stage, it is important to clearly identify possible risk factors, threats, also the strengths and capabilities of the final product. Innovative production structures needs either in startup capital or investment support for the development of new high technologies, which can be solved with the participation of various investors with state support. For an innovative structure of production character requires initial capital or investment support from both the state and private investors in order to further application of a new advanced technologies, which determines the relevance of the participation of various state- 
supported investors. In other words, public authorities create conditions for a scientific researches with financial support in conjunction with private investors.

The production of products and its further sale are typical for the placement stage, with using the «7P» marketing-mix concept - of a wide range of marketing tools based on an integrated marketing approach. This is all detailed in a business-plan, i.e., a document that describes all aspects of the company's activities that are important for investors and partners. As an investor can be various industrial companies of certain industries, interested in further using of the commercialization product in the production process.

In other words, commercialization as the process of bringing a product-innovation to the market includes the following stages (Rodina G.E., Ochekovskaya L.P., 2015):

1) the first stage is associated with the assessment and selection of the most profitable innovative ideas and products for bringing them to the market. This process is accompanied by conducting an expert examination of such indicators as: the potential of a product-innovation, its demand in the market, including in a certain market segment - a potential buyer, economic profitability during the sale of products, as well as the payback period, net present value, rate of return, and etc.;

2) within the framework of the enterprise's innovation policy, the second stage is characterized by conducting of marketing researches, aimed at identifying of the prospects for product development-innovation. These researches are characterized by the collection, processing and analysis of information about the internal and external environment of the enterprise with the further development of the necessary recommendations, proposals in the framework of the implementation of effective strategic and tactical management decisions;

3) within the framework of the third stage of the commercialization process, the financial resources are formed, necessary for the implementation of innovative ideas. The main task of enterprises at this stage is to attract investors, whose funds will be directed to the innovative development of the enterprise, the creation of innovation with the assignment of rights to it and distribution among all participants of the process;

4) the final stage of commercialization - the fourth, is characterized by such features as the organization of the production process of innovative products with their subsequent implementation, then the inculcation of this product into the production process.

There are three main participants in the process of innovations commercialization: inventor, manager, and investor, each of them meant to fulfill his role in implementing the company's innovation policy. By the inventor can be a researcher in a scientific organization or a free inventor performing the functions of the technical author of the project. Employees of the commercialization Center who are intermediaries between the author and the external environment can be project managers. This category of participants has knowledge, experience and skills in the field of generating and receivings of a profit. Because managers who only have a general idea about the technical idea of the inventor, they are not able to understand the main features of the profit-making technology, their primary task is to build a profitable business process for all project participants aimed at generating cash flow.

An investor can be a person, a group of persons, or a separate organization (venture or other fund). This category of participants is very important for the project, because thanks to his financial support, the implementation of its main tasks is carried out. The implementation of the main functions of investors occurs through technical, economic, financial expertise, by attracting consultants forming recommendations about the need to invest in the project based on a detailed analysis.

Based on the foregoing, it should be pointed out that all persons involved in the project of R\&D results commercialization play an important role, and all of them are necessary for its successful implementation (Varenik V.A., 2012).

There are two categories of participants involved by the commercialization of innovative products: developers and buyers of innovations. It is also worth noting another important participant in this process, acting as centers for transfer and commercialization of innovations, innovation centers, various consulting companies, business-incubators that performing intermediary functions between innovations developers and their buyers (Shchetinina E.D., Ovcharova N.V., 2015).

In the Republic of Kazakhstan, the technology transfer network is represented by six national and international technology transfer networks:

1. Russian technology transfer network;

2. Republican center of technologies transfer (Republic of Belarus);

3. The national network of technologies transfer (Ukraine);

4. The American stock exchange innovation Yet2Com; 
5. The European market of technologies transfer;

6. Database of UNIDO.

Recently, the Kazakh-French center for technology transfer and the Korean-Kazakh center of technological cooperation (further - the Center) have also been operating, their activities are aimed at ensuring cooperation between companies and research institutions in Kazakhstan and South Korea, Kazakhstan and France, also selecting of investors, partners and technologies. These Centers coordinate joint scientificallyresearch and innovation projects by organizing joint programs for training and development of personnel in the field of creating innovations and supporting joint innovation initiatives.

According to the Decree of the Republic of Kazakhstan Government № 959 dated 23.12.2019, JSC "Center of engineering and technologies transfer" is included in the list of the national development institutions in the field of technological development. The center performs the following functions:

- Unified coordinator of the innovation ecosystem;

- providing of the innovative grants;

- rendering of services of the national innovation system institutions.

Today, in the process of innovations commercialization, an important point is to choose of the method of commercialization, which can be expressed in the form of independent using; assignment of part of the rights to innovation; or full transfer of rights to innovation.

When implementing of the first method of commercialization, the company needs to generate labor and financial resources, using of which contributes to the successful implementation of innovative products. When applying an effective production management system, it is important that the product is in demand among potential consumers. By placing a bet on the second or third method of commercialization, the company will be able to return the funds spent on innovation and development in a short time.

Основной задачей при реализации способов коммерциализации является определение и расчет доходов и расходов предприятия при коммерциализации инноваций (Таблица 2).

The license sale is accompanied by the "transfer" of a part of the market to the licensee by the enterprise and the receipt of stable income (royalties), the opportunity to promote innovation at the expense of the licensee in new markets. In the case of a full transfer or sale of the rights on innovation, there is a possibility of receiving income equivalent to income from own production. Because the company will lose all rights for using its own developments, the company will need to change the direction of its activities (Lyashin A., 2011).

The main task in the implementation of commercialization methods is to determine and calculate the income and expenses of an enterprise at the innovations commercialization (Table 2).

Table 2. The enterprise incomes and expenses at the innovations commercialization

\begin{tabular}{|l|l|l|}
\hline Commercialization methods & \multicolumn{1}{|c|}{ The enterprise incomes } & \multicolumn{1}{|c|}{ The enterprise expenses } \\
\hline Independent using & $\begin{array}{l}\text { Making a profit from: } \\
\text { - an innovation sales; } \\
\text { - providing of engineering services; } \\
\text { - leasing of machinery and equipment. }\end{array}$ & $\begin{array}{l}\text { Implementation of costs for: } \\
\text {-organization of the production process; } \\
\text { - marketing researches and advertising } \\
\text { campaign; } \\
\text { - modification or modernization of prod- } \\
\text { ucts. }\end{array}$ \\
\hline $\begin{array}{l}\text { Assignment of the rights part } \\
\text { to innovation }\end{array}$ & $\begin{array}{l}\text { Proceeds from the license sale (lump- } \\
\text { sum payment); } \\
\text { Payments from the using by the licen- } \\
\text { see of the patent (royalties). } \\
\text { Making a profit from: } \\
\text { - a license sales; } \\
\text { - using by the licensee of the patent } \\
\text { (royalty). }\end{array}$ & $\begin{array}{l}\text { - modification or modernization of prod- } \\
\text { - attracting clients (licensees); } \\
\text { - provision of consulting services to the } \\
\text { licensee; } \\
\text { - protection of patent rights. }\end{array}$ \\
\hline $\begin{array}{l}\text { Complete transfer of all in- } \\
\text { novation rights }\end{array}$ & $\begin{array}{l}\text { Proceeds from the patent rights sale } \\
\text { (lump-sum payment). } \\
\text { Making a profit from: } \\
\text { - sale of patent rights (lump-sum } \\
\text { payment). }\end{array}$ & $\begin{array}{l}\text { Implementation of costs for: } \\
\text {-attraction of the buyer; } \\
\text { - assistance to the buyer, protection of his } \\
\text { rights. }\end{array}$ \\
\hline Note: compiled by the authors on the basis of source (Shpak $N .$, Kniaz S., Myroshchenko N., Kolomiyets O., 2017)
\end{tabular}


After analyzing of the table, the matter can be summed up that the company will receive the greatest benefits from the independent implementation of the developed innovative products (i.e. organizing new products or modernizing existing ones). At the same time, this method of commercialization will be expensive, because it will require organizing and maintaining the production process at the enterprise, conducting of marketing activities (including advertising activities).

A relatively small income will be generated by the using of assignment of the rights parts to innovations. Because license buyers will receive only a portion of the profit from all their income, then the costs will be relatively small. Due to the fact that most of the company's expenses are related to finding and attracting customers, the company must have additional reserves to search for foreign customers in case of a shortage in their country.

The potential profit in the course of the independent innovation implementation (excluding leasing and engineering services) can be calculated using the formula (Tikhonov N.A., 2012):

$$
\mathrm{P}_{\mathrm{T} 1}={ }_{\mathrm{ti}} \sum^{\mathrm{tf}} \mathrm{V}_{\mathrm{t}} \times \Delta \mathrm{P}_{\mathrm{t}} \times \mathrm{K}_{\mathrm{dt}}
$$

where: $\mathrm{P}_{\mathrm{T} 1}$ - is the potential profit from the goods and services sales of own production for the period T, expressed in monetary units;

$\mathrm{V}_{\mathrm{t}}$ - is the volume of products sales per year $\mathrm{t}$, expressed in grands;

$\Delta \mathrm{P}_{\mathrm{t}}$ - is the expected profit from the sale of a unit of product in $\mathrm{t}$ year, expressed in monetary units;

$\mathrm{K}_{\mathrm{dt}}$ - discount coefficient in $\mathrm{t}$ year;

ti and $\mathrm{tf}$ - initial and final years of the settlement period $\mathrm{T}$.

Profit in the event of the assignment of the rights part or their complete transfer is calculated as follows:

$$
\mathrm{P}_{\mathrm{T} 2}=\mathrm{S} \times{ }_{\mathrm{ti}} \sum^{\mathrm{tf}} \mathrm{V}_{\mathrm{t}} \times \Delta \mathrm{P}_{\mathrm{t}} \times \mathrm{K}_{\mathrm{dt}}
$$

where: $\mathrm{P}_{\mathrm{T} 2}$ - is the potential profit from the licenses or patents sales for the period $\mathrm{T}$ (including leasing, franchising, engineering services), in monetary units;

$\mathrm{S}$ - is the share of the copyright holder in the buyer's profit of the patent or license, in \%.

If $\mathrm{P}_{\mathrm{T} 1}>\mathrm{P}_{\mathrm{T} 2}$, then for the enterprise the best option would be independent using of the developed innovation, but if $\mathrm{P}_{\mathrm{T} 1}<\mathrm{P}_{\mathrm{T} 2}$, then it is more profitable to sell licenses, patents for innovation.

\section{Discussions}

Many authors identify the concept of " innovations commercialization" with the concept of "innovation process", linking it with the stage of the innovation process, from the beginning with the start of production and ending with the decline of the product lifecycle. Until now, there is no single definition of the concept of "innovations commercialization", "process of commercialization". In other words, there are some shortcomings that are still not fully disclosed in the framework of the theoretical approach.

Because the innovations development is an expensive and risky process, there are difficulties associated with financing and state support for the innovations development. In the article an attempt to schematically display the commercialization process is made, in which the state and venture capital play an important role. In other words, today it is important to create the necessary conditions for research and development by the public authorities, providing financial support together with private investors.

In order to ensure the successful implementation of an innovation, should pay attention to the commercialization process at an earlier stages, starting from the fundamental researches, identifying opportunities for innovation commercialization at all stages of its creation.

Each side of the innovation commercialization project plays an important role. The activities of the three parties mentioned in the article should have formal relations and restrictions if there is a project implementation program. At the same time, due attention should be paid to the functioning of the Centers of commercialization, which are designed to provide consulting services (consultations) to all participating parties.

In the future, will be studied the features of the commercialization process, typical for Kazakhstan's innovation system, an organizational and economic model of the innovation commercialization process will be developed.

\section{Conclusions}

In conclusion, it should be noted that the innovations commercialization as a process is characterized by quite complex phenomena associated with the development and implementation of preparatory measures of a scientific, technical, financial and marketing nature. At the same time, it is important to assess the potential risks of the project. Successful implementation and ensuring of an effective management of the innovations 
commercialization process contributes to the creation of favorable conditions for the developer of innovation and the state as a whole (Barinova N., Nazarova T., 2018).

Commercialization as a key element of the innovation process, aims to create basic conditions for the successful implementation of innovation and effective commercialization of innovation. Enterprises should focus on choosing of the method of its implementation, because it is the basis for improving of the competitiveness of the product and the profitability of the enterprise as a whole.

To consider the process of innovations commercialization in a terms of the sequence of its stages, from the moment of turning a scientific idea into an innovative product brought to the consumer, contributes to a step-by-step analysis of the results of this process. A theoretical approach to the process of innovations commercialization from the point of view of an investment project helps to take into account possible financial risks, estimating of the required funding amount, and, if necessary, apply measures related to minimizing financial losses.

\section{References}

Aarikka-Stenroos, L., Sandberg, B., \& Lehtimäki, T. (2014). Networks for the commercialization of innovations: A review of how divergent network actors contribute. Industrial Marketing Management, 43, 365-381. doi:10.1016/j.indmarman.2013.12.005

Bozeman, B. (1997). Commercialization of federal laboratory technology: results of a study of industrial partners. New Technology-Based Firms in the 1990s., 3. - 127-139.

Belitski, M., Aginskaja, A., \& Marozau R. (2019). Commercializing university research in transition economies: Technology transfer offices or direct industrial funding? Research Policy, 48(3), 601-615. doi:10.1016/j.respol.2018.10.011

Barinova, N.V., \& Nazarova T.N. (2018). Teoreticheskie podhody k kommercializacii innovacij [Theoretical approaches to the commercialization of innovations]. ETAP - STAGE, 4, 49-59. doi: 10.24411/2071-6435-2018-10036 [in Russian].

Dewangan, V., \& Godse, M., (2014). Towards a holistic enterprise innovation performance measurement system. Technovation, 34 (9), 536-545. doi: 10.1016/j.technovation.2014.04.002

Dehghani, T. (2015). Technology commercialization: From generating ideas to creating economic value. International Journal of Organizational Leadership, 4, 192-199.

El-Haj-Hassan B. (2004). Firm size and technology commercialization in Canada's biotechnology and manufacturing sectors with a focus on medium-sized firms. Thesis. Ottawa, Canada.

Grik, Ya.N. \& Monastyrnyj, E.A. Resursnyj podhod k postroeniyu biznes-processov i kommercializacii razrabotok [Resource approach to building business-processes and commercializing developments]. Innovacii-Innovations, 7 , 85-87 [in Russian].

Glukhov, V.V., Korobko, S.B., \& Marinina, T.B. (2003). Ekonomika znanij [Knowledge Economy], 528. [in Russian].

Global'nyj innovacionnyj indeks (Gii) 2020. [Global Innovation Index (GII) 2020]. globalinnovationindex.org Retrieved from https://www.globalinnovationindex.org/ [in Russian].

Iskoskov, M.O. \& Vyacheslavovna-Chernova, D. (2013). Methods for Commercializing the Results of the Innovation Project. Middle-East Journal of Scientific Research, 13(5), 670-674. doi:10.5829/idosi.mejsr.2013.13.5.1952

Industry Canada. (2006). People and excellence: The heart of successful Commercialization, 2, 10. Retrieved from https://present5.com/implementing-canada-s-innovation-strategy-engaging-stakeholders-in-policy

Jordan, J.F. (2014). Innovation, Commercialization, and the Successful Startup in Life Sciences, 11, 1-226 doi:10.1201/b17287

Kalynychenko, M. P. (2012). Marketing kommercializacii rezul'tatov innovacionnoj deyatel'nosti v promyshlennosti [The marketing of innovation activity results commercialization in industry]. Marketing $i$ menedzhment innovacijMarketing and management of innovations, 4, 43-50 [in Russian].

Kozmetskij, Dzh. (1999). Vyzov tekhnologicheskih innovacij na poroge novoj ery obshchemirovoj konkurencii [The challenge of technological innovation on the threshold of a new era of global competition]. Transfer tekhnologii $i$ effektivnaya realizaciya innovacij - Transfer technologies and effective implementation of innovations, 296 [in Russian].

Lukash, Yu.A. (2004). Enciklopedicheskij slovar'-spravochnik rukovoditelya predpriyatiya [Encyclopedic dictionary of the head of the enterprise]. M.: Knizhnyj mir, 1503. [in Russian].

Lyashin, A. (2011) Strategii kommercializacii innovacij — most mezhdu innovatorom i biznesom [Innovation commercialization strategies - a bridge between innovator and business]. Ekonomika i zhizn' - Economy and life, 36 (9402), 356 [in Russian].

Lai, P.C. (2018). Research, Innovation and Development Strategic Planning for Intellectual Property Management. Economic Alternatives, 3, 303-310. doi:10.13140/RG.2.2.31629.38888

Mamrayeva, D.G. (2017). Issledovanie processa kommercializacii innovacij v Respublike Kazahstan i mekhanizm ego upravleniya [Research of the commercialization of innovations process in the Republic of Kazakhstan and the mechanism of its management]. Karaganda: Izdatel'stvo KarHU [in Russian]. 
Mohannak, K., \& Samtani, L. (2014). A Criteria-based Approach for Evaluating Innovation Commercialization. In Proceedings of the DRUID Society Conference, 1-15. Retrieved from https://eprints.qut.edu.au/72214/17/Mohannak___A_criteria-based_approach_-_DRUID14_Conference.pdf

Morozov, Yu.P. (1997). Innovacionnyj menedzhment [Innovation management]. Moscow: Progress [in Russian].

Nikkanen, J.-M. (2018). Game theory supporting commercialization process of a start-up company. Master's Thesis. Oulu Business School.

Orlova, K.V. (2017) Etapy processa kommercializacii innovacij [Stages of the innovation commercialization process]. Vestnik Voronezhskogo gosudarstvennogo universiteta. Seriia Yekonomika i upravlenie - Bulletin of the Voronezh State University. Economics and Management series, 3, 45-49 [in Russian].

Olefirenko, O. \& Shevliuga, O. (2017). Commercialization of innovations: peculiarities of sales policy at innovation active enterprise. Innovative Marketing, 13(2), 6-12. doi:10.21511/im.13(2).2017.01

Rogers, D.S., Lambert, D.M. \& Knemeyer, A.M. (2004). The Product Development and Commercialization Process. International Journal of Logistics Management, 15, 43-56. doi:10.1108/09574090410700220

Rodina, G.E., \& Ochekovskaya, L.P. (2015). Teoreticheskie aspekty kommercializacii innovacij [Theoretical aspects of commercialization of innovations]. Vestnik Altajskoj nauki-Bulletin of the Altai Science, 3(4), 48-52 [in Russian].

Shpak, N., Kniaz, S., Myroshchenko, N., \& Kolomiyets, O. (2014). Commercialization of high-tech products: theoretical-methodological aspects. Econtechmod. An international quarterly journal, 3(1), 81-88.

Slak-Madsen, S.K., Ritter, T. \& Sornn-Friese, H. (2017). Commercialization in Innovation Management: Defining the Concept and a Research Agenda. In: Academy of Management Annual Meeting Proceedings, 8, 15880. doi: 10.5465/AMBPP.2017.15880abstract

Shchetinina, E.D., \& Ovcharova, N.V. (2015). Sposoby kommercializacii innovacij i roli posrednikov v processe kommercializacii innovacij [Ways to commercialize innovations and the role of intermediaries in the process of commercializing innovations]. Vestnik Belgorodskogo gosudarstvennogo tekhnologicheskogo universiteta im. V.G. Shuhova - Bulletin of the Belgorod State Technological University named after V.G. Shukhov, 4, 127-129 [in Russian].

Trifilova, A.A. (2005). Ispol'zovanie innovacionnogo podhoda v strategicheskom upravlenii predpriyatiem [Using an innovative approach in the strategic management of an enterprise]. Pravo. Ekonomika. Marketing. - Right. Economy. Marketing, 5, 38-39 [in Russian].

Tihonov, N.A. (2012). Effektivnost' sposobov kommercializacii innovacij [Effectiveness of commercialize innovations ways]. Upravlenie ekonomicheskimi sistemami: elektornnyj nauchnyj zhurnal - Management of economic systems: electronic scientific journal, 4 (40), 104 [in Russian].

Varenik, V.A. (2012). Sovremennye tendencii v teorii kommercializacii innovacij [Modern trends in the theory of innovations commercialization]. Transportnoe delo Rossii. Ekonomika. - Transport business in Russia. Economy, 4, 4344 [in Russian].

Zakon Respubliki Kazakhstan ot 31 oktyabrya 2015 goda No. 381-V “O kommertsializatsii rezultatov nauchnoi i nauchno-tekhnicheskoi deiatelnosti” (s izmeneniyami ot 25.06.2020 g.) [Law of the Republic of Kazakhstan dated October, 31, 2015 No. 381-V "On the commercialization of the results of scientific and scientific-technical activities" (as amended on 25.06.2020)]. online.zakon.kz. Retrieved from https://online.zakon.kz/document/?doc_ id $=31806330$ [in Russian].

\section{Д.Г. Мамраева, А.Б. Токсамбаева, Г.Б. Мамраева, Л.А. Родина}

\section{Инновацияларды коммерцияландыру процесін зерттеудің теориялық аспектілері}

\section{Aндатnа:}

Maқcambl: Теориялық және әдіснамалық аспектілерді, сондай-ақ инновацияларды коммерцияландыру процесін басқару тетіктерін қарастыру.

Әдісі: Мақалада жүйелік және құрылымдық талдау, соның ішінде зерттелетін ғылыми мәселелерді жанжақты қарастыруға мүмкіндік беретін, сондай-ақ зерттелетін зерттеу объектісінің мәні мен ерекшелігін толық ашатын қорытынды жасау әдістері қолданылды.

Kорытынды: Мақалада инновацияларды коммерцияландыру теориясындағы заманауи үрдістер қарастырылды, инновацияларды коммерцияландыру саласындағы ұғымдық аппарат зерделенді; инновацияларды коммерцияландыру процесі зерттелді, оның қатысушыларының өзара байланысы анықталды, оны жүзеге асыру тәсілдері айқындалды; инновациялық процестің кезеңдері мен фазалары нақтыланды.

Тұжырымдама: Ұсынылған ғылыми мақалада инновацияны коммерцияландыру, инновациялық процесс ұғымдары, оны жүзеге асыру кезеңдері зерттелген. Мақалада инновациялық процестің негізгі фазалары мен кезеңдері сипатталған, инновацияларды коммерцияландыру моделі, сондай-ақ оны сәтті жүзеге асыру дәрежесінің критерийлері талданған. Инновацияларды коммерцияландыру әдістері сипатталды, қазіргі кездегі ең өзекті, белгілі бір кезеңдегі әлеуетті пайда, инновацияларды коммерцияландыру процесін сәтті жүзеге асырған кезде кәсіпорынның кірістері мен шығыстарының негізгі баптары ұсынылды. Инновациялық өнімді коммерцияландырудың белгілі бір кезеңіндегі әлеуетті пайданы есептеу формулалары көрсетілген. Шетелдік 
және отандық зерттеушілердің, авторлардың талданған ғылыми зерттеулерінде қазіргі экономикалық даму, әлем елдерінің бірқатар экономикаларын цифрлық және инновациялық құрамдас бөліктерге қайта құру жағдайында, коммерцияландыру инновациялық қызмет нәтижелерін табысты енгізудің маңызды компоненттерінің бірі болып табылады, сондықтан бұл процесті компаниялардың ҒЗТКЖ саласындағы қызметінің құрылымында іргелі зерттеулер жүргізген сәттен бастап ертерек кезеңдерде жүзеге асырған жөн.

Kiлm сөздер: инновациялар, инновацияларды коммерцияландыру процесі, инновациялық қызмет кезеңдері, инновациялық жоба, нәтижелерді коммерцияландыру, ҒЗТКЖ, инновацияларды коммерцияландыру тетігі, инновацияларды коммерцияландыру схемасы.

\section{Д.Г. Мамраева, А.Б. Токсамбаева, Г.Б. Мамраева, Л.А. Родина}

\section{Теоретические аспекты изучения процесса коммерциализации инноваций}

\section{Аннотация}

Цель: Рассмотреть теоретико-методологические аспекты, а также механизмы управления процессом коммерциализации инноваций.

Memoдbl: В статье использованы методы системного и структурного анализа, позволяющие рассматривать исследуемую в статье научную проблематику комплексно, а также делать выводы, полно раскрывающие сущность и специфику изучаемого объекта исследования.

Результаты: В статье изучены современные тенденции в теории коммерциализации инноваций, понятийный аппарат в области коммерциализации инноваций; исследован процесс коммерциализации инноваций, установлена взаимосвязь его участников, определены способы его осуществления; конкретизированы этапы и фазы инновационного процесса.

$B b l в о д b l:$ В статье исследовано понятие коммерциализации инноваций, инновационного процесса, этапы его осуществления. Описаны основные фазы и стадии инновационного процесса, проанализирована модель коммерциализации инноваций, а также критерии степени ее успешного осуществления. Охарактеризованы способы коммерциализации инноваций, наиболее актуальные на сегодняшний день, представлены потенциальная прибыль за определенный период, основные статьи доходов и расходов предприятия при успешной реализации процесса коммерциализации инноваций. Отражены формулы расчета потенциальной прибыли за определенный период коммерциализации инновационного продукта. В проанализированных научных исследованиях зарубежных и отечественных исследователей, авторами сделан вывод о том, что в условиях современного экономического развития, перестройки ряда экономик стран мира на цифровую и инновационную составляющие, коммерциализация служит одной из важнейших компонентов успешного внедрения результатов инновационной деятельности, поэтому целесообразно осуществлять данный процесс на более ранних этапах, начиная с момента проведения фундаментальных исследований компаниями в структуре их деятельности в сфере НИОКР.

Ключевые слова: инновации, процесс коммерциализации инноваций, этапы инновационной деятельности, инновационный проект, коммерциализация результатов, НИОКР, механизм коммерциализации нововведений, схема коммерциализации инноваций.

\section{References}

Aarikka-Stenroos L. Networks for the commercialization of innovations: A review of how divergent network actors contribute / L. Aarikka-Stenroos, B. Sandberg, T. Lehtimäki // Industrial Marketing Management. — 2014. № 43. - P. 365-381. doi:10.1016/j.indmarman.2013.12.005

Belitski M. Commercializing university research in transition economies: Technology transfer offices or direct industrial funding? / M. Belitski, A. Aginskaja, R. Marozau // Research Policy. — 2019. — №48(3). — P. 601-615. doi:10.1016/j.respol.2018.10.011

Bozeman B. Commercialization of federal laboratory technology: results of a study of industrial partners. [Text] / B. Bozeman // New Technology-Based Firms in the 1990s. — London: Paul Chapman Publishing. — 1997. — Vol. 3. - P. 127-139.

Dewangan V. Towards a holistic enterprise innovation performance measurement system / M. Godse // Technovation. — 2014. — № 34 (9). — P. 536-545. doi: 10.1016/j.technovation.2014.04.002

Dehghani T. Technology commercialization: From generating ideas to creating economic value / T. Dehghani // International Journal of Organizational Leadership. — 2015. — № 4. — P. 192-199.

El-Haj-Hassan B. Firm size and technology commercialization in Canada's biotechnology and manufacturing sectors with a focus on medium-sized firms. [Thesis] / B. El-Haj-Hassan // Ottawa, Canada. — 2012. — P.10.

Iskoskov M.O. Methods for Commercializing the Results of the Innovation Project. / M. Iskoskov, D. VyacheslavovnaChernova // Middle-East Journal of Scientific Research. — 2013. — № 13(5). — P. 670-674. doi:10.5829/idosi.mejsr.2013.13.5.1952

Industry Canada. People and excellence: The heart of successful Commercialization. — 2006. — Vol.2. — P. 10. Retrieved from https://present5.com/implementing-canada-s-innovation-strategy-engaging-stakeholders-in-policy 
Jordan J.F. Innovation, Commercialization, and the Successful Startup in Life Sciences / J.F. Jordan // Innovation, Commercialization, and the Successful Startup in Life Sciences. — 2014. — 11. — P. 1-226 doi:10.1201/b17287

Lai P.C. Research, Innovation and Development Strategic Planning for Intellectual Property Management. / P. Lai // Economic Alternatives. — 2018. — № 3. - P. 303-310. doi:10.13140/RG.2.2.31629.38888

Mohannak K. A Criteria-based Approach for Evaluating Innovation Commercialization. / K. Mohannak, L. Samtani // Proceedings from: DRUID Society Conference on Entrepreneurship — Organization — Innovation. Copenhagen Business School, Denmark. - 2014. - P. 17.

Nikkanen J.-M. Game theory supporting commercialization process of a start-up company. [Text]: Master's Thesis /. J.M. Nikkanen // Oulu Business School. - 2018. - P. 68.

Olefirenko O. Commercialization of innovations: peculiarities of sales policy at innovation active enterprise / O. Olefirenko, O. Shevliuga // Innovative Marketing. — 2017. - Vol.13. — № 2. - P. 6-12. doi:10.21511/im.13(2).2017.01

Rogers D.S. The Product Development and Commercialization Process. / D. Rogers, D. Lambert, A. Knemeyer // International Journal of Logistics Management. — 2004. — № 15(1). — P. 43-56. doi:10.1108/09574090410700220

Shpak N. Commercialization of high-tech products: theoretical-methodological aspects / N. Shpak, S. Kniaz, N. Myroshchenko, O. Kolomiyets // Econtechmod. An international quarterly journal. — 2014. — № 3(1). - P. 8188.

Slak-Madsen S.K. Commercialization in Innovation Management: Defining the Concept and a Research Agenda / S. Slak-Madsen, T. Ritter, H. Sornn-Friese // Academy of Management Annual Meeting Proceedings. — 2017. — № 8. - P. 15880. doi: 10.5465/AMBPP.2017.15880abstract

Баринова Н.В. Теоретические подходы к коммерциализации инноваций / Н.В. Баринова, Т.Н. Назарова // ЭТАП. - 2018. - № 4. - С. 49-59.

Вареник В.А. Современные тенденции в теории коммерциализации инноваций / В.А. Вареник // Транспортное дело России. Экономика. - 2012. - № 4. - С. 43, 44.

Грик Я.Н. Ресурсный подход к построению бизнес-процессов и коммерциализации разработок / Я.Н. Грик, Е.А. Монастырный // Инновации. - 2004. — № 7. - С. 85-87.

Глухов В.В. Экономика знаний [Текст] / В.В. Глухов, С.Б. Коробко, Т.Б. Маринина. — СПб.: Питер, 2003.$528 \mathrm{c.}$

Глобальный инновационный индекс (Гии), 2020. (https://www.globalinnovationindex.org/).

Закон Республики Казахстан от 31 октября 2015 года № 381-V «О коммерциализации результатов научной и (или) научно-технической деятельности» (с изм. от 25.06.2020г.). — (https://online.zakon.kz/document/? doc_id=31806330)

Калиниченко М.П. Маркетинг коммерциализации результатов инновационной деятельности в промышленности / М.П. Калиниченко // Маркетинг и менеджмент инноваций. - 2012. — № 4. - С. 43-50.

Козметский Дж. Вызов технологических инноваций на пороге новой эры общемировой конкуренции // Трансфер технологии и эффективная реализация инноваций / под ред. Н.М. Фонштейн. - М.: АНХ, 1999. 296 c.

Лукаш Ю.А. Энциклопедический словарь-справочник руководителя предприятия / Ю.А. Лукаш. - М.: Книжный мир, 2004. - 1503 с.

Ляшин А. Стратегии коммерциализации инноваций — мост между инноватором и бизнесом / А. Ляшин // Экономика и жизнь. - 2011. — № 36 (9402). — С. 356.

Мамраева Д.Г. Исследование процесса коммерциализации инноваций в Республике Казахстан и механизм его управления: моногр. / Д.Г. Мамраева. - Караганда: Изд-во КарГУ, 2017. — 158 с.

Морозов Ю.П. Инновационный менеджмент / Ю.П. Морозов. - М.: Прогресс, 1997. — 187 с.

Орлова К.В. Этапы процесса коммерциализации инноваций / К.В. Орлова // Вестн. Воронеж. ун-та. Сер. Экономика и управление. - 2017. - № 3. - С. 45-49.

Родина Г.Е. Теоретические аспекты коммерциализации инноваций / Г.Е. Родина, Л.П. Очековская // Вестн. Алтайской науки. - 2015. - № 3(4) - С. 48-52.

Тихонов Н.А. Эффективность способов коммерциализации инноваций / Н.А. Тихонов // Управление экономическими системами: электрон. науч. журн. — 2012. — № 4 (40). — С. 104.

Трифилова А.А. Использование инновационного подхода в стратегическом управлении предприятием / А.А. Трифилова // Право. Экономика. Маркетинг. — 2005. — № 5. - С. 38, 39.

Щетинина Е.Д. Способы коммерциализации инноваций и роли посредников в процессе коммерциализации инноваций / Е.Д. Щетинина, Н.В. Овчарова // Вестн. Белгород. гос. технол. ун-та им. В.Г. Шухова. — 2015. № 4. - С. 127-129. 